\title{
Bringing Indigenous Knowledge into Physics Learning Instruments for Enhancing Students' Data Literacy: Its feasibility and practicality
}

\author{
T D Purwita ${ }^{1, *}$ D Rosana ${ }^{2}$ \\ ${ }^{1}$ Physics Education, Graduate Schools, Universitas Negeri Yogyakarta, Yogyakarta, Indonesia \\ ${ }^{2}$ Science Education, Graduate Schools, Universitas Negeri Yogyakarta, Yogyakarta, Indonesia \\ *Corresponding author. Email: tanty.purwita@gmail.com
}

\begin{abstract}
This research aims to (1) determine the feasibility and practicality of indigenous knowledge-based learning instruments, and (2) measure the suitability of test items to be measured students' data literacy abilities. This study uses a 4D model research and development. Data collection techniques use assessment sheets and test items. These assessment sheets are given to three lecturers, and 2 physics teachers, while data literacy test items are given to 265 students from class XII as research subjects. The research places were conducted in Senior High School 1 Turen and Senior High School 1 Bululawang, Malang, East Java. This physics learning instruments consisted of lesson plans, student worksheets, and assessment of data literacy tests. The study results were analysed with qualitative and quantitative descriptive. Based on the assessment sheet result, it is known that the physics learning instruments based on indigenous knowledge have the feasibility and practicality in the excellent category with a total average has greater value than 3.25. Meanwhile, based on the QUEST analysis results, 10 items of data literacy questions have high reliability. However, two out of ten items of data literacy do not suitable for use in the implementation of indigenous knowledge-based learning instruments in Physics classrooms.
\end{abstract}

Keywords: Indigenous knowledge, data literacy, feasibility, reliability.

\section{INTRODUCTION}

As a result of technological growth in data collection, human life is becoming increasingly dependent on data flow (or big data) [1],[2]. Competitive nation civilization also resulted in heterogeneity development in the data information flow and it has an impact on human social life [3]. At present, society must coexist with data in various activities, especially decision making. Decision making based on data because data can be analysed or processed to create information. Then, the information obtained can produce knowledge that can help us to make better decisions [4]. Thus, the importance of the ability to process data is needed [5]. Intellectual ability to collect, manage, evaluate, and apply data, is critically referred to as the ability of data literacy [6].

Data literacy can be considered a life skill because human interaction with data is becoming increasingly common. Data literacy skill is not limited to certain people but needed the whole community [3]. Every society can be equipped with the skills needed to become a data literate society through data literacy competencies in school [7], [8]. However, the capabilities of data literacy are not consistent in the public, private, or academic sectors yet. Data literacy training requires a foundation for the community. This training can be started with data literacy competencies in schools. As an educator, the teacher needs special knowledge, skills, and dispositions to use data effectively before teaching it to students in schools [8].

In Table 1, the indicator of data literacy skills can be summarized into 4 parts [9]. 
Table 1. Indicators and sub-indicator of data literacy

\begin{tabular}{|c|c|}
\hline Indicators & Sub-indicator \\
\hline $\begin{array}{l}\text { Observation } \\
\text { of data }\end{array}$ & $\begin{array}{l}\text { Read data in the form of shapes, } \\
\text { images, graphs, tables, and diagrams }\end{array}$ \\
\hline $\begin{array}{l}\text { Collection of } \\
\text { data }\end{array}$ & Interpreting the data obtained \\
\hline $\begin{array}{l}\text { Data } \\
\text { Appraisal }\end{array}$ & $\begin{array}{l}\text { Calculate data based on information in } \\
\text { the form of graphs, tables or diagrams } \\
\text { obtained }\end{array}$ \\
\hline $\begin{array}{l}\text { Application } \\
\text { of data }\end{array}$ & $\begin{array}{l}\text { Summarize and show information } \\
\text { based on data results }\end{array}$ \\
\hline
\end{tabular}

Indigenous knowledge generally develops from the daily activities or habits of the local people [10], [11]. Indigenous knowledge can develop and become local wisdom that can be known well in society. One of the local-wisdom in East-Java is patrol music as a product of cultural locality in the Bandulan area, Malang [12]. Patrol music has become a tradition that has a function as a signal for the sahoor of the Muslim community during the month of Ramadan [13]. Until now, patrol music has become a way of life for the people of Malang City during Ramadan.

Indigenous knowledge-based learning can provide simple learning innovations for student character development [14]. It can be a learning innovation that generally attract students' interest in new learning. Students' interest hardly utilized during learning without vary innovation learning that created by teacher in the classroom [15], [16], [17], [18]. Indigenous knowledge needs to be introduced from an early age to students in the current era of technological development. Technological developments have always been a challenge to local wisdom which requires modernization in every aspect of human life. Therefore, the development of local wisdom-based learning can be one of the alternative lessons for the preservation of local culture as well as improving aspects of data literacy skills as a necessity in modern human life.

\section{METHODS}

\subsection{Types and Subjects}

This study used 4D research and development. Data retrieval used three expert lecturers, 2 physics teachers, and 265 students of class XII as research subjects. The research places were conducted in two schools, namely Senior High School 1 Turen and Senior High School 1 Bululawang, Malang, East Java.

\subsection{Design and Instruments}

This study aims to determine the feasibility and practicality of the learning instruments and measure the appropriateness of the data literacy test items. The learning instruments' feasibility is needed before it is implemented as a measurement tool for students' data literacy abilities. Physics learning instruments in this study consist of lesson plans, student worksheets, and assessment of data literacy tests. The design of students' worksheets is integrated with patrol music in the form of "kentongan" illustrations and patrol music information. The lesson plans design uses discovery learning models with sound wave subjects based on indigenous knowledge. Besides indigenous knowledge, the test item was also adjusted to the data literacy indicator. Before the main test assessment activities on students, observations were also made on students of class XII to determine the students' condition.

\subsection{Data Analysis}

The data collection technique used two instruments namely the assessment sheet of the instrument feasibility and data literacy test items. The data literacy test item consisted of 10 essay questions. The data acquisition test results in the form of values range from one to 5 . If students answer correctly and completely will get a value of 5, whereas if the student's answer is wrong then students get a value of 1 . All research results are analysed descriptively qualitatively and quantitatively descriptive. The product feasibility assessment is given to 3 expert lecturers and this assessment sheet is guided by the conversion of answers into scale values 1 to 4 . Then, the sum score $\left(\sum x\right)$ for each aspect in assessment sheets is divided by 3 assessors as judgements. The average value $\left(Y^{-}\right)$for each aspect can be obtained with equation (1).

$$
\bar{Y}=\frac{\sum x}{n}
$$

with $\mathrm{n}$ is the number of assessors or responses. The average score for each aspect can be converted into qualitative data with four-scale that it is shown in Table 2 below [19].

Table 2. Converting A Score To A Category Scale Of 4

\begin{tabular}{|c|c|}
\hline Interval Value & Category \\
\hline $3,25<x \leq 4$ & Very Feasible \\
\hline $2.5<x \leq 3.25$ & Feasible \\
\hline $\mathbf{1 . 7 5}<\boldsymbol{x} \leq \mathbf{2 . 5}$ & Moderate \\
\hline $\mathbf{1}<\boldsymbol{x} \leq \mathbf{1 . 7 5}$ & Less Feasible \\
\hline
\end{tabular}

Measurement of test instruments with QUEST use Table 3 and Table 4 to study the suitability of test data 
items from the level of reliability and level of item suitability.

Table 3. Interpretation of reliability

\begin{tabular}{|c|c|}
\hline Value & Category \\
\hline $\mathbf{- 1 . 0 0} \leq \boldsymbol{r} \leq \mathbf{0 . 2 0}$ & Lowest \\
\hline $\mathbf{0 . 2 0}<\boldsymbol{r} \leq \mathbf{0 . 4 0}$ & Low \\
\hline $\mathbf{0 . 4 0}<\boldsymbol{r} \leq \mathbf{0 . 6 0}$ & Moderate \\
\hline $\mathbf{0 . 6 0}<\boldsymbol{r} \leq \mathbf{0 . 8 0}$ & Reliable \\
\hline $\mathbf{0 . 8 0}<\boldsymbol{r} \leq \mathbf{1 . 0 0}$ & Very Reliable \\
\hline
\end{tabular}

Table 4. Criteria for item in quest

\begin{tabular}{|c|c|c|c|}
\hline \multicolumn{2}{|c|}{ Compatibility with the Rasch Model } & Difficulty Index & Criteria for Item \\
\cline { 1 - 2 } Infit MNSQ $(x)$ & Outfit $t$ & & \\
\hline $\mathbf{0 , 7 7} \leq \boldsymbol{x} \leq \mathbf{1 , 3 3}$ & $t \leq 2,00$ & $-2 \leq b \leq 2$ & Suitable \\
\hline $\mathbf{0 , 7 7} \leq \boldsymbol{x} \leq \mathbf{1 , 3 3}$ & $t \leq 2,00$ & $b>2$ or $b>-2$ & Moderate \\
\hline $\boldsymbol{x}<\mathbf{0 , 7 7}$ or $\boldsymbol{x}>\mathbf{1 , 3 3}$ & $t>2,00$ & $b>2$ or $b<-2$ & Not Suitable \\
\hline
\end{tabular}

\section{RESULTS AND DISCUSSION}

This research uses patrol music that has a connection with Physics subject, namely sound waves. Sound wave based on indigenous knowledge is integrated into the learning instruments developed. In more detail, the indigenous knowledge-based student worksheet display is presented in Figures 1 and 2.

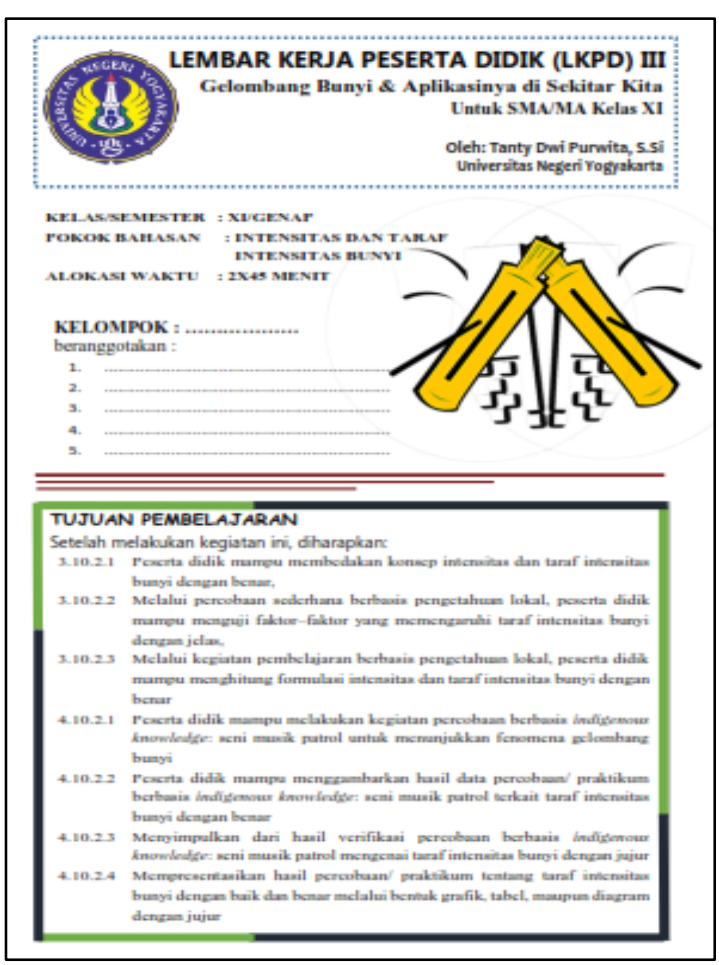

Figure 1 The front page of Student Worksheets III

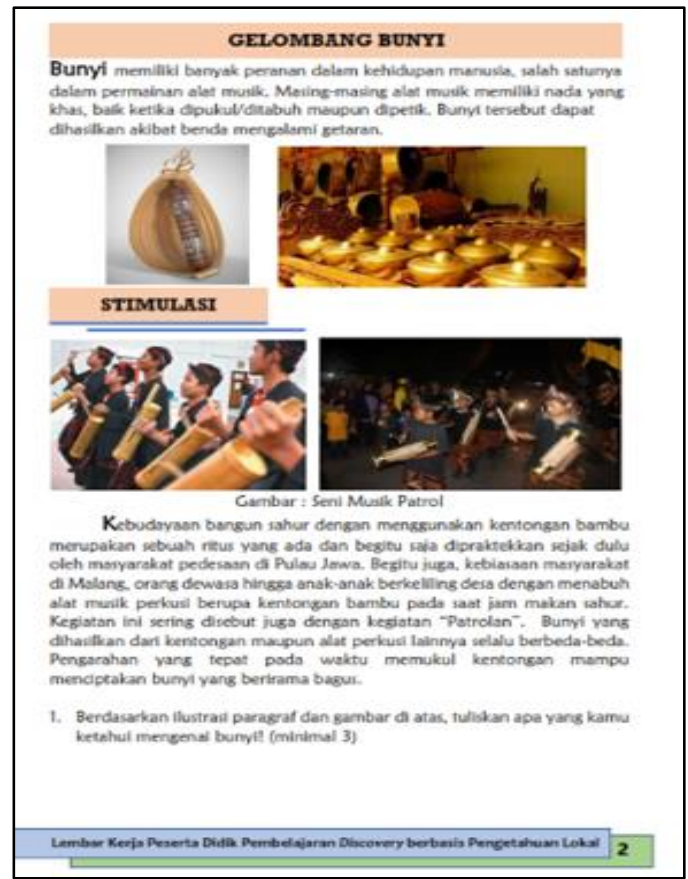

Figure 2 Information about patrol music inside student worksheet ("stimulation" stage)

This study aims to determine the feasibility and practicality of indigenous knowledge-based physics learning instruments and the suitability of data literacy test items to be used. The development of indigenous knowledge-based learning instruments products was given to 3 lecturers and 2 Physics teachers to check the 
feasibility and practicality of the product. Based on the literature study, some of the findings are summarized as evaluation components of indigenous knowledge-based learning instrument products. These components become some references in making learning instruments and feasibility assessments by assessors. The component in the lesson plan and student worksheets are shown in Table 5 and 6.

Table 5. Evaluation components of lesson plan

\begin{tabular}{|c|c|}
\hline Rated aspects & Sub-Aspects \\
\hline \multirow{9}{*}{$\begin{array}{l}\text { The Lesson Plan } \\
\text { Component }\end{array}$} & Completeness of Lesson plan components in accordance with "Permendikbud" No. 22 of 2016 \\
\hline & Complete lesson plan identity in accordance with "Permendikbud" No. 22 of 2016 \\
\hline & The suitability of the formulation of indicators with basic competencies \\
\hline & $\begin{array}{l}\text { The suitability of the formulation of learning objectives with indicators of competency } \\
\text { achievement }\end{array}$ \\
\hline & $\begin{array}{l}\text { Match learning objectives with the structure of form A (audience), B (behaviour), C (condition) } \\
\text { and D (degree) }\end{array}$ \\
\hline & The suitability of teaching materials with the formulation of competency achievement indicators \\
\hline & The suitability of teaching materials with the formulation of learning objectives \\
\hline & The suitability of teaching materials with approaches, models, and learning methods used \\
\hline & The suitability of teaching materials with the level of understanding of students \\
\hline \multirow[t]{3}{*}{ Learning Activities } & The suitability of learning activities with the discovery learning model \\
\hline & $\begin{array}{l}\text { The suitability of the learning activity scheme with the development of learning instruments } \\
\text { based on indigenous knowledge }\end{array}$ \\
\hline & The suitability of learning activities in developing aspects of data literacy abilities \\
\hline \multirow[t]{2}{*}{ Linguistic } & Use of language according to PUEBI (General Guidelines for Indonesian Spelling) \\
\hline & Simple sentence structure \\
\hline $\begin{array}{l}\text { Indigenous } \\
\text { Knowledge }\end{array}$ & The use of indigenous knowledge in learning activities with discovery learning models \\
\hline
\end{tabular}

Table 6. Evaluation components of students worksheet

\begin{tabular}{|c|c|}
\hline Rated Aspect & Sub-aspects \\
\hline \multirow{4}{*}{$\begin{array}{l}\text { Content } \\
\text { Feasibility }\end{array}$} & Suitability of students' worksheet components \\
\hline & Suitability of students' worksheet contents \\
\hline & The suitability of the discovery learning model in students' worksheet activities \\
\hline & $\begin{array}{l}\text { The suitability of the elaboration of indicators of achievement and standard competencies in the } \\
\text { learning objectives in students' worksheet }\end{array}$ \\
\hline \multirow{4}{*}{$\begin{array}{l}\text { Didactic } \\
\text { Feasibility }\end{array}$} & Suitability of material sequence in students' worksheet \\
\hline & Students worksheet facilitates the activities of high school level students \\
\hline & Compliance with the instructions for using students' worksheet \\
\hline & Availability of appropriate questions and direct students actively in the learning process \\
\hline \multirow[t]{3}{*}{ Linguistic } & The suitability of the use of Indonesian in students' worksheet \\
\hline & Suitability of sentence structure in students' worksheet \\
\hline & Clarity of information in students' worksheet \\
\hline \multirow[t]{2}{*}{ Presentation } & The suitability of the use of writing (font) in students' worksheet \\
\hline & Appropriate placement of information, illustrations / pictures / photos in students' worksheet \\
\hline
\end{tabular}




\begin{tabular}{|l|l|}
\hline & Appropriateness of layout, design and pages in students' worksheet \\
\hline $\begin{array}{l}\text { Indigenous } \\
\text { Knowledge }\end{array}$ & The use of indigenous knowledge: patrol music art in students' worksheet \\
\hline
\end{tabular}

The results of learning instrument appraisal were obtained from 3 expert lecturers with the result of average value for each aspect is shown in Table 7 and 8 below:

Table 7. Feasibility results of lesson plan

\begin{tabular}{|l|c|c|}
\hline \multicolumn{1}{|c|}{ Rated Aspect } & Average & Category \\
\hline The components & 3.48 & Very Feasible \\
\hline Learning Activities & 3.55 & Very Feasible \\
\hline Linguistic & 3.33 & Very Feasible \\
\hline Indigenous Knowledge & 3.33 & Very Feasible \\
\hline \multicolumn{1}{|c|}{ Total Average } & $\mathbf{3 . 4 3}$ & Very Feasible \\
\hline
\end{tabular}

Table 8. Feasibility results of student worksheet

\begin{tabular}{|l|c|c|}
\hline \multicolumn{1}{|c|}{ Rated Aspect } & Average & Category \\
\hline Content Feasibility & 3.58 & Very Feasible \\
\hline Didactic Feasibility & 3.67 & Very Feasible \\
\hline Linguistic & 3.11 & Feasible \\
\hline Presentation & 3.78 & Very Feasible \\
\hline Indigenous Knowledge & 3.67 & Very Feasible \\
\hline Total Average & $\mathbf{3 . 5 6}$ & Very Feasible \\
\hline
\end{tabular}

An assessment from 3 expert lecturers described feasibility on all components of the indigenous knowledge-based learning instrument. Based on Tables 7

Table 9. Practical results of learning instrument by practitioners

\begin{tabular}{|l|c|c|}
\hline \multicolumn{1}{|c|}{ Rated Aspect } & $\begin{array}{c}\text { Average } \\
\text { Value }\end{array}$ & Category \\
\hline Learning & 3.50 & Very Feasible \\
\hline Material (Content) & 3.75 & Very Feasible \\
\hline Media Visual & 3.75 & Very Feasible \\
\hline Indigenous Knowledge & 4.00 & Very Feasible \\
\hline Total Average & 3.75 & Very Feasible \\
\hline
\end{tabular}

Table 10. Sample questions of the data literacy test

\begin{tabular}{|l|c|}
\hline \multicolumn{1}{|c|}{ Indicators } & \multicolumn{1}{c|}{ Item tests } \\
\hline $\begin{array}{l}\text { Observation of } \\
\text { data }\end{array}$ & $\begin{array}{l}\text { Village heads and villagers sound some kentongan on the hill to signal danger. Two seconds } \\
\text { later the sound was heard by Mr. Andi, who was looking for wood behind the hill. What is the } \\
\text { distance between Mr. Andi and the residents on the hill? }(v=300 \mathrm{~m} / \mathrm{s}) \\
\text { Collection of }\end{array}$
\end{tabular}

and 8 the results show the lesson plan feasibility has 3.43 as the total average value. This value is categorized quite feasible. This result was also obtained from the student worksheet based on indigenous knowledge (patrol music art) which has a total average value of 3.56. Thus, indigenous knowledge-based students' worksheets have excellent feasibility. This feasibility research shows that indigenous knowledge in the learning process design can be integrated. The research from Syaban and Wilujeng [20] shows that learning instruments based on local wisdom can be developed so it has expediency to be used in increasing scientific literacy. In others research by Khusniati, et.al. [14] shows that indigenous knowledge actually can be also integrated into learning instruments for student's conservationist character.

Assessment by the Physics teacher shows the practicality of the learning instruments to be applied to the classroom of students. Based on Table 9 below, the assessment of learning instruments that have been developed shows the value in terms of learning, material, media visual and indigenous knowledge has a greater value than 3 , which is categorised as quite feasible category. So, this learning instrument can be used in the classroom because it has a very feasible category of its practicality. In Table 10 presents some sample questions of data literacy test that have been used in this research. 


\begin{tabular}{|c|c|c|c|}
\hline Data Appraisal & \multicolumn{3}{|c|}{$\begin{array}{l}\text { The sound intensity level of "kentongan" made of bamboo is } 30 \mathrm{~dB} \text {. If the threshold sound intensity } \\
\text { level of } 10^{-11} \mathrm{~W} / \mathrm{m}^{2} \text {, what is the sound intensity level for } 100 \text { similar "kentongan" that can be } \\
\text { produced in a patrol musical art performance? }\end{array}$} \\
\hline \multirow[t]{6}{*}{$\begin{array}{l}\text { Application of } \\
\text { data }\end{array}$} & \multicolumn{3}{|c|}{$\begin{array}{l}\text { In the month of Ramadan, patrol music performances are held at } 3 \text { different places. It is known } \\
\text { that the distance table between a listener and each source of the "kentongan" sound is played at } \\
\text { points } P, Q \text {, and R as follows: }\end{array}$} \\
\hline & Sound Source Point & Sound Power (Watt) & Distance to listener $(\mathrm{m})$ \\
\hline & $P$ & 314 & 10 \\
\hline & $Q$ & 3.140 & 20 \\
\hline & $\mathrm{R}$ & 31.400 & 40 \\
\hline & \multicolumn{3}{|c|}{ Based on the information in the table, which of the three places has the greatest sound intensity? } \\
\hline
\end{tabular}

Table 11. Summary of item and case estimate in quest result

\begin{tabular}{|l|c|c|c|c|}
\hline & Mean & SD (adjusted) & $\begin{array}{c}\text { Reliability of } \\
\text { Estimate }\end{array}$ & $\begin{array}{c}\text { Category for } \\
\text { Reliability }\end{array}$ \\
\hline Item Estimates & 0.01 & 0.41 & 0.75 & Reliable \\
\hline Case Estimates & -0.31 & 0.32 & 0.59 & Moderate \\
\hline
\end{tabular}

Besides the feasibility of the lesson plan and students' worksheet, the usage of the data literacy items has to need the appropriate requirements with the Rasch model criteria and have good reliability. In Table 11 is shown three from 10 items of data literacy test that has been used in the QUEST analysis. Based on Table 3 as a reference, it can be seen in the "item estimates" part in Table 10. All data literacy items have 0.75 value. This value indicates 10 data literacy test items have high reliability.
While the reliability of the items, the reliability of the research subjects (265 students) was also analyzed based on their ability level. Based on the reliability value "case estimates" in Table 11, it obtained a value of 0.59 . This value means that the participant's reliability in this study is included in a moderate category or quite reliable. Thus, this value can be concluded that the repetition of the test with other test participants can produce the results that have moderate stability (moderate consistency).

Table 12. Empirical test analysis results on item data literacy test

\begin{tabular}{|c|c|c|c|c|c|}
\hline Item Number & DIFFICULTY & Diff. Index & INFIT MNSQ & INFIT t & Criteria for Item \\
\hline 1 & -0.37 & Moderate & 1.51 & 6.7 & Not suitable \\
\hline 2 & 0.30 & Moderate & 1.15 & 1.6 & Suitable \\
\hline 3 & -0.73 & Moderate & 0.96 & -0.4 & Suitable \\
\hline 4 & 0.03 & Moderate & 0.98 & -0.3 & Suitable \\
\hline 5 & -0.73 & Moderate & 0.98 & -0.3 & Suitable \\
\hline 6 & 0.26 & Moderate & 0.88 & -1.5 & Suitable \\
\hline 7 & 0.33 & Moderate & 0.84 & -1.7 & Suitable \\
\hline 8 & 0.69 & Moderate & 0.84 & -1.3 & Suitable \\
\hline 9 & 0.36 & Moderate & 0.69 & -2.9 & Not suitable \\
\hline 10 & -0.15 & Moderate & 1.12 & 1.7 & Suitable \\
\hline
\end{tabular}

Table 12 shows the item analysis results on each item. The results of Table 11 provide information in the form of item difficulty level for each item, namely in the DIFFICULTY column. The higher the value in the 
DIFFICULTY column, then shows the difficult item is very high. Based on the results in Table 10, the whole item of data literacy items has a moderate level of item difficulty. However, based on the INFIT MNSQ (Infit MEAN SQUARE) and Outfit $t$ value indicate that item number 1 and number 9 do not match the specified value range. Thus, out of 10 data literacy test items, 2 items are not suitable and the items don't fit the Rasch model. Based on the results of Table 11, it can be concluded that the developed indigenous knowledge-based learning instruments contained 8 valid items to measure students' data literacy abilities.

\section{CONCLUSION}

Based on the analysis results, the indigenous knowledge based-learning instruments development has feasibility and practicality to be used in the classroom for enhancing students' data literacy skills. All test items for data literacy measurement have a moderate level of difficulty. However, two out of 10 items of data literacy items from indigenous knowledge based-learning instruments do not fit the criteria of good items to be applied in class.

\section{ACKNOWLEDGMENTS}

Authors would like to gratitude the Directorate of Research and Community Service, Directorate General of Higher Education, Ministry of Education and Culture and Institute and also The Institute of Research and Community Service for funding and management, Universitas Negeri Yogyakarta and Senior High School in Malang Regency that supports this study.

\section{REFERENCES}

[1] D'Ignazio C, Bhargava R. Approaches to building big data literacy. In Proceedings of the Bloomberg data for good exchange conference. 2015.

[2] Mandinach, E. B., \& Gummer, E. S. Navigating the Landscape of Data Literacy: It IS Complex. WestEd. 2012. pp. 8-13

[3] Twidale, M. B., Blake, C., \& Gant, J. Towards a Data Literate Citizenry. IConference 2013 Proceedings. 2013. https://doi.org/10.9776/13189

[4] Herzog, D. Data literacy: a user's guide. SAGE Publications. 2015.

[5] Koltay, T. Data literacy: in search of a name and identity. Journal of Documentation, vol. 71 No. 2. 2015. pp. 401-415. https://doi.org/10.1108/JD02-2014-0026

[6] EDC's Oceans of Data Institute (ODI). Building Global Interest in Data Literacy: A DialogueWorkshop Report. Education Development Center, Inc. 2016. pp. 2-4

[7] Prado, J. C., \& Marzal, M. Á. Incorporating data literacy into information literacy programs: Core competencies and contents. Libri, 63(2). 2013. pp: 123-134. doi: http://10.1515/libri-2013-0010

[8] Mandinach, E. B., \& Gummer, E. S. What does it mean for teachers to be data literate: Laying out the skills, knowledge, and dispositions. Teaching and Teacher Education. 60. 2016. 366-376. DOI: https://doi.org/10.1016/j.tate.2016.07.011

[9] Ridsdale, C., Rothwell, J., Smit, M., Ali-Hassan, H., Bliemel, M., Irvine, D., ... \& Wuetherick, B. Strategies and best practices for data literacy education: Knowledge synthesis report. 2015. DOI: http://10.13140/RG.2.1.1922.5044

[10] Avery, L. M. Rural science education: Valuing local knowledge. Theory Into Practice, 52(1). $2013.28-35$. doi: https://doi.org/10.1080/07351690.2013.743769

[11] Mawere, M. Indigenous knowledge and public education in sub-Saharan Africa. Africa Spectrum. 50(2). 2015. 57-71. doi: https://doi.org/10.1177/000203971505000203

[12] Maftuchin, A. S., \& Budiyanto, A. Tradisi Seni Patrol dan Identitas Budaya Kampung Bandulan di Kota Malang. Studi Budaya Nusantara, 1(1), $2017.46-54.40$ https://doi.org/10.21776/ub.sbn.2017.oo1.01.05

[13] Tri Wulandari, A. G. N. E. S., \& Mariana, N. Eksplorasi Konsep Matematika Sekolah Dasar pada Seni Tradisi di Desa Trowulan Mojokerto. Jurnal Penelitian Pendidikan Guru Sekolah Dasar, 6(7). 2018.

[14] Khusniati, M., Parmin, \& Sudarmin. Local Wisdom-Based Science Learning Model Through Reconstruction of Indigenous Science to Improve Student's Conservationist Character. Journal of Turkish Science Education. 2017. DOI: https://doi.org/10.12973/tused.10202a

[15] Purwita, T. D., Sari, L. P., \& Wilujeng, I. Utilizing of TTW (Think-Talk-Write) instructional model in the use of pictorial riddle-aided student worksheets for students' critical thinking skills enhancement. Journal of Physics: Conference Series, $\quad 1440(1) . \quad 2020 . \quad$ DOI: https://doi.org/10.1088/17426596/1440/1/012046

[16] Amirin, T. M. Implementasi Pendekatan Pendidikan Multikultural Kontekstual Berbasis Kearifan Lokal di Indonesia. Jurnal pembangunan pendidikan: Fondasi dan aplikasi, 1(1). 2012. doi: https://doi.org/10.21831/jppfa.v1i1.1047

[17] Sukma, T. A., Mundilarto, M., \& Putri, N. D. Local wisdom-Based Electronic Book on Newton's Law. Jurnal Ilmiah Pendidikan Fisika Al-Biruni. 8(2), 2019. pp.197-206. DOI: https://doi.org/10.24042/jipfalbiruni.v0i0.4368

[18] Naqiyah, M., Rosana, D., Sukardiyono, \& Ernasari. Developing physics learning tools based on local wisdom in the form of musical instrument of gandrang bulo dance as learning source in sound wave. Journal for the Education of Gifted Young Scientists. 7(3), 2019: 609-626. DOI: 
https://doi.org/10.17478/jegys.599902

[19] Widoyoko, E. P. Teknik penyusunan instrumen penelitian. Yogyakarta: Pustaka Pelajar. 2012.

[20] Syaban, M. F., \& Wilujeng, I. Pengembangan SSP zat dan energi berbasis keunggulan lokal untuk meningkatkan literasi sains dan kepedulian lingkungan. Jurnal Inovasi Pendidikan IPA, 2(1), $2016 . \quad 66-75 . \quad$ doi: https://doi.org/10.21831/jipi.v2i1.8369 